Council, at which an international group of interested persons discussed terminology of some aspects of gas exchange in the lungs, in particular the term 'diffusing capacity'. The participants represented Belgium, France, Germany, Great Britain, Holland, Scandinavia, Switzerland, and the United States. Dr. P. Hugh-Jones, Departmont of Medicine, King's College Hospital Medical School, London, was chairman. When the term 'diffusing capacity' was originally proposed, it was considered that diffusion was the only factor determining the rate of transfor of gas between alveolar capillary blood and alveo. lar gas. It is now known that the rate of reaction between carbon monoxide, oxygen and intracollular hæmoglobin, as well as other factors, affect the transfor rate. In addition the diffusing capacity as actually measured is depondent on additional variables, such as the ventilation perfusion relationship in the lungs. In the light of these considerations, the majority of those present agreed that the term 'transfer factor' be substituted for 'diffusing capacity', but no definite proposal was made that this be carried out immediately. Persons interested in this field of rosearch and wishing to submit thoir views should write to J. E. Cotes, Medical Research Council Pneumo. coniosis Research Unit, Llandough Hospital, Penarth, Glamorgan.

\section{Causes and Treatment of Rheumatic Disease}

During May 29 30, 1962, the Nuffield Foundation held a small two-day conference at Ashridge Colloge, at which scientists from various biological disciplines discussed with rheumatologists the possible nature of fundamental rheumatic processes. 'This exchange of ideas between clinical and non-clinical research workers proved stimulating, and the Foundation believes that the report of the papers and discussion may be of value to other people. A copy of the report may be obtained (without charge) by writing to the Nufficld Foundation, Nuffield Lodge, Regent's Park, London, N.W.1.

International Commission on Zoological Nomenclature

Norrce is hereby given of the possible use by the International Commission on Zoological Nomenclature of its plenary powers in connexion with the following cases, full details of which will bo found in Bulletin of Zoological Nomenclature (20, Part 5, to be published on October 21): (1) Designation of a type-species for Crassispira Swainson, 1840 (Gastropoda). Z.N.(S.) 459. (2) Validation of Alycus Koch, 1842 (Acari). Z.N.(S.) 465. (3) Validation of Natrix barbouri Taylor, 1922 (Reptilia). Z.N.(S.) 1559. (4) Suppression of Conus candidus Born, 1778 (Gastropoda). Z.N.(S.) 1567. (5) Suppression of Pleuronectes grohmanni Bonaparte, 1837 (Piscos). Z.N.(S.) 1579. (6) Validation of, and designation of a type-species for, Diplectrona Westwood, 1839 (Insecta, Trichoptera). Z.N.(S.) 1580. (7) Validation of Sceloporus torquatus Wiegmann, 1828 (Roptilia). Z.N.(S.) 1582. (8) Validation of Ortholitha Hubner, [1825] (Insecta, Lepidoptera). Z.N.(S.) 1585. (9) Validation of Krohnia Langerhans, 1880 (Chaetog. natha). Z.N.(S) 1586. (10) Suppression of nine specific names of Holothurioidea. Z.N.(S.) 1587. (11) Supprossion of Eoscorpius inflatus Poach, 1882 (Arachnida). Z.N.(S.) 1588. (12) Validation of Prochilodus argenteus Agassiz, 1829 (Pisces). Z.N.(S.) 1590. (13) Validation of Tinodes pusillus McLachlan, 1862 (Insecta, Trichoplera). Z.N.(S.) 1592. (14) Rejection of the nootype and type-locality of Thamnophis sirtalis (Linnaous) (Reptilia). Z.N.(S.) 1600. Any zoologist who wishes to comment on any of the foregoing cases should do so in writing to the Secretary, International Commission on Zoological Nomenclature, c/o British Museum (Natural History), Cromwoll Road, London, S.W.7, beforo April 21, 1964.

\section{The International Academy of Astronautics}

Dr. Charles S. Draper (United States) has been appointed president of the International Acadomy of
Astronautics in succession to Dr. F. J. Malina. Dr. Draper is head of the Department of Aeronautics and Astronautics at the Massachusetts Institute of Technology, as well as diroctor of the Institute's Instrumentation Laboratory. Prof. E. A. Brun (France), president of the International Astronautical Federation, and Prof. U. S. von Euler (Sweden), secretary of the Nobel Prize Committee, have been elected vice-presidents. Tho following Acadomicians have been elected to the Board of Trustoes of the International Academy of Astronautics: Section IBasic Sciences, Prof. A. Ehmert (German Fodoral Republic) and Dr. D. F. Martyn (Australia); Section 2-Engineering Sciences, Prof. J. M. J. Kooy (Holland), Dr. F. J. Malina (United States) and Prof. R. Peśek (Czechoslovakia); Section 3-Life Sciences, Dr. W. R. Lovelace II (United States) and Air Commodore W. K. Stewart (United Kingdom).

\section{Announcements}

Prof. Linus Pauling, of the California Institute of Technology, has been awarded the Nobel Peace Prize for 1962. In 1954 Prof. Pauling was awarded the Nobel Prize for Chemistry (see Nature, 174, 907; 1954). He is a foreign member of the Royal Society.

The Right Hon. Lord Franks, Provost of Worcester College, Oxford, and former chairman of Lloyds Bank, and Prof. R. H. S. Thompson, professor of chemical pathology, Guy's Hospital Medical School, have been appointed additional trustees of the Wellcome Trust.

A LEAFLet, Another Kind of School, has been issued by the National Association for Mental Health for parents of children who aro not accepted for school, describing the Junior 'Training Centres and other openings and facilities available to enable montally handicapped children to make the best use of their abilities (Pp. 4. London: Association for Montal Health, 1963. 6d.).

THF third Western National Meeting of the American Geophysical Union will be held in Boulder, Colorado. during December 26-28. Further information can be obtained from W. W. Kellogg, the Rand Corporation, 1700 Main Streot, Santa Monica, California.

THE eighth international conference on "Cosmic Rays", arranged under the joint auspices of the International Union of Pure and Applied Physics and the Department of Atomic Energy, Government of India, will be held at Jaipur during December 2-14. Further information can be obtained from Dr. R. R. Daniel, Tata Institute of Fundamental Research, Colaba, Bombay 5.

The National Productivity Ycar Conference, "Productivity in the Next Five Years", will bo held at Eastbourne during November 26-28. The conference is being organized by the Department of Scientific and Industrial Research and its aim is "to compare notos, to discuss future action and to provide a guide for firms and organizations in everty sector of our working life". Further information can be obtained from the Secretary, British Productivity Council, Vintry House, Quoen Street Place. London, E.C.4.

A ONE-DAY course on "Aspects of Microbiology and Plant Protection" will be held by the Joint Biology Committee at tho William Beveridge Hall, Senate House. London, W.C.1, on Novomber 16. Tho programme will include: "Microbiology of the Air", by Dr. P. H. Gregory; "The Migration and Dispersal of Aphids and the Dissemination of Plant Viruses", by Dr. C. G. Johnson; "Somo Chemical Aspects of Crop Protection", by Prof. R. L. Wain; "Modern Methods of Plant Protoction and the Consorvation of Wildlifo", by Dr. N. W. Moore. Furthor information and tickets ean be obtained from the Joint Biology Committon, c/o the Associntion of Agriculture, 78 Buckingham Gate, London, S.W.1. 